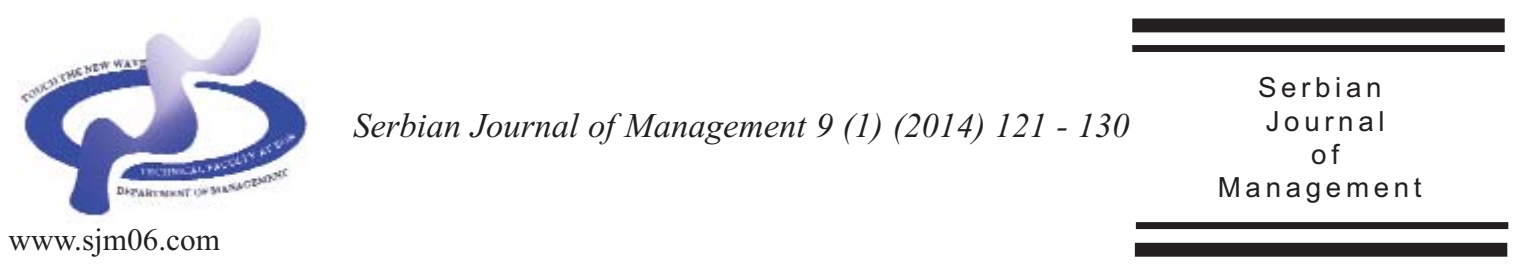

\title{
WHY WE NEED 100 PERCENT RENEWABLE ENERGIES: A PLEA FOR THE ENERGIEWENDE
}

\author{
Christian Hinsch* and Felix Wächter \\ Corporate Communications juwi group, juwi AG Energie-Allee 1, \\ 55286 Wörrstadt, Germany
}

(Received 18 March 2014; accepted 26 March 2014)

\begin{abstract}
Those familiar with the fifth intergovernmental Penal on Climate Change report presented in late 2013 can no longer seriously doubt that climate change has become a reality. Although the issue has been the subject of several high profile international conferences, little has been achieved so far. Fossil power plants still continue to emit massive amounts of greenhouse gases further accelerating climate change. There is, however, an alternative to our current climate-damaging way of energy production: The complete transition towards 100 percent renewable energies. This paper examines the way in which an industrialized country like Germany can become a 100 percent renewable by 2020 .
\end{abstract}

Keywords: Energiewende, renewable energies, Germany, transition, fossil fuels, Matthias Willenbacher, juwi

\section{INTRODUCTION}

There has been no change of the initial situation that paved the way for Germany's decision to transformation its energy sector away from fossil and nuclear fuel towards a sustainable and more climate friendly power production since the late 1990s.

Coal-fired power plants still continue to emit enormous amounts of greenhouse gases further accelerating climate change. Nobody seriously doubts the fact any more that the emission of greenhouse gases directly influencesthe global climate in a negative way - at least no one who is not pursuing contrary economic interests. The IPCC FifthAssessmentReport published in September 2013 puts it very clearly:

\footnotetext{
* Corresponding author: Hinsch@juwi.de
}

DOI:10.5937/sjm9-5752 
"Warming of the climate system is unequivocal, and since the 1950s, many of the observedchanges are unprecedented over decades to millennia. The atmosphere and ocean have warmed, the amounts of snow and ice have diminished, sea level has risen, and the concentrations ofgreenhouse gases have increased" (IPCC, 2013).

Moreover, there is a broad consensus in the scientific community that climate change is in fact man-made. For more than 150 years, since the beginning of the industrialization in the second half of the eighteenth century, the industrialized countries emit more climate-damaging carbon dioxide than the atmosphere can cope with. "Human influence on the climate system is clear. This is evident from the increasing greenhouse gas concentrations in the atmosphere, positive radiative forcing, observed warming, andunderstanding of the climate system"(IPCC, 2013). The IPCC report further states that "human influence has been detected in warming of the atmosphere and the ocean, in changes in the global water cycle, in reductions in snow and ice, in global mean sea level rise, and in changes in some climate extremes. This evidence for human influence has grown since AR4. It is extremely likely that human influence has been the dominant cause of the observed warming since the mid-20th century" (IPCC, 2013).

Furthermore, the imminent danger for humankind and the environment that comes with nuclear energy is still ubiquitous. Chernobyl and Fukushima have become the synonym for nuclear accidents of catastrophic dimensions. The accidents in Harrisburg, Sellafield, Majak, Tomsk-7 and Tokaimure have already demonstrated the uncontrollability of nuclear technology before. Until today, no safe nuclear waste storage concept has been developed. In other words: The problem regarding the final disposal of nuclear waste is still unresolved.

In Germany, the nuclear accident in Fukushima has led to the gradual phasing out of nuclear power. But there are more than ethical and moralargumentsthat clearly speak against nuclear power. Even from an economic perspective, the eraof nuclear power production is finally over. Despite years of direct and indirect state subsidies, financial aid, tax concessions and other benefitting conditions of more than 213 billion Euro in Germany alone, the allegedly favorable nuclear power has been proven to be uneconomical (Küchler et al., 2012). As soon as additional political privileges aredropped - such as the externalization of follow-up costs in the case of a nuclear accident or the extensive release of radioactivity - the unprofitability of this technology becomes even more obvious.

Even in the United States- a country that proclaimed the nuclear renaissance a few years ago - a gloomy mood proliferates among operators of nuclear power plants. "Within market economy conditions the construction of new nuclear power plants has already been impossible for quite a long time. New, however, is the fact that even the operation of old, fully amortized nuclear power plants is no longer economically viable", the internationally renowned nuclear expert Mycle Schneider analyzed for the German renewable energy website klimaretter.info in late 2013 (Schneider, 2013, own translation). Despite a few new construction projects, nuclear power is globally in the retreat (Schneider \& Frogatt, 2013).

As a consequence, neither nuclear energy nor fossil fuels can be considered a solution for the fight against climate change. The 
latter in particular isnot just climate killer number one, the price for oil, gas and coal is also constantly rising. Was the price per barrel crude oil only 17 US Dollars in 1999, it dramatically increased to 109 US Dollars in 2012 (Mineralölwirtschaftsverband e.V., 2013). This is a price increase of more than 600 percent!

Concerning this trend, no significant changes can be expected prospectively as the shortage of resources and the increasing exploration costs will proceed in the upcoming decades: a rising demand is facing a simultaneously decreasing supply: Peak oil, the so-called height in oil exploration, has already been exceeded.

In the fight against climate change and the lasting shortage of resources the switch to renewable energies such as wind-, water- and solar power is "the only chance for mankind" (Scheer et al., 1998, own translation), Hermann Scheer, one of the pioneers of Germany's renewable energy act (Erneuerbare-Energien-Gesetz, EEG) already stated in 1998. According to Sheer, Alt and Claus the major advantage of renewables over fossil fuels is the fact that they do not issue any invoices - their energy is infinite and for free. Combined, these climate-friendly sources of energy form an inexhaustible potential that provides 15,000 times more energy than is consumedglobally (Willenbacher, 2013). Their potential just needs to be utilized.

All technologies for a sustainable, clean, reliable and safe energy production are already in place: Today, modern wind turbines reliably and economically produce clean electricity, even in so-called low-wind areas. With the power of the sun, photovoltaic (PV) modules produce clean electricity exactly when it is needed the most: at midday when Germany's energy intensive industry is in full swing and in high demand for electricity.

It is Germany's energy-intensive industry in particular that benefits from renewable energies the most. Thanks to the so-called Merit-Order-Effect ${ }^{1}$, PV reduces the price for electricity traded at Germany's EEX electricity exchange in Leipzig (Wirth, 2013). Unlike private households, Germany's industry is able to buy electricity at lower prices directly at the EEX spot market: a great advantage that immediately benefits Germany's industry (Schumann, 2013). Additionally, the industry profits from lowEEX electricity prices for long-term procurements. While private householdsin 2013 paid an average electricity price of 28,78 cent/kWh (BDEW, 2013), large-scale costumers have already been able to conclude long-term electricity procurements for a fixed price of 4 cent $/ \mathrm{kWh}$ up to and including the year 2020 (IWR, 2013).

Because of all these benefits the Energiewende is societal consensus in Germany. The overwhelming majority of the population supports the transition into a fossil- and nuclear-free future and does not want a relapse into the old system (Emnid, 2013), a public opinion survey prior to the German general elections in autumn 2013 reveals.

\section{THE RADICAL RESTRUCTURING OF ENERGY SUPPLY}

The Energiewende - the transformation of Germany's centralistic and fossil fuel based energy system towards a clean, safe, sustainable and decentralized system based on renewable energies - is currently the most challenging economic and socio-political project in the country's post-WW II era. This

\footnotetext{
${ }_{1}^{1}$ As a result of the priority feed-in for electricity generated from renewable resources the electricity supply increases at the EEX. In order to meet the electricity demand, green electricity is used first. Conventional electricity is pushed out of the market as a consequence resulting in lower prices.
} 
transition, however, comes with major changes: Inflexible, large-scale fossil fuel plants are no longer compatible with the requirements of a flexible and decentralized power production on the basis of renewable energies.A complete change of system is therefore required - a change that comes with nothing less than the radical restructuring of today's energy market.

\section{SYSTEM CONFLICT ON THE GERMAN ENERGY MARKET}

"The increasing expansion of fluctuating renewable energies (in particular wind- and solar energy) leads to the situation that base load in the classical sense is continuously decreasing and will be non-existent in the foreseeable future. Instead, flexible power plants are needed to accompany the fluctuating feed from renewable sources", the Fraunhofer Institute for Solar Energy Systems ISE states in a recent study (Mayer et al., 2013). The study's results illustrate how inadequately the required transition is currently taking place. Although the share of renewables in the generation of power has continuously increased over the years, the power production system is still miles away from the demands of a flexible generating structure. The results of the ISE's study show in full detail that

- $\quad$ in the first half of 2013 the numbers of low prices hours $(<10 € / \mathrm{MWh})$ have almost doubled compared to the first half of 2012

- the numbers of hours with negative prices increased by roughly 50 percent

- in sum, the net electricity exports in the first half of 2013 almost doubled from 8.8 terawatt hours (TWh) to $15.6 \mathrm{TWh}$ compared to the first six months of 2012.
These are all indicators of a heavy, inflexible and totally incompatible fleet of power stationsfor the requirements of Energiewende. Additionally, lignite-based power plants continued to operate with a high utilization of 83 percent, respectively 73 percent, in times of a negative or a low trading price of electricity. Consequently, the production of lignite-based electricity increased by 2 TWh and the production of hard coal-based electricity by 4 TWh comparing the first six months of 2012 with the first half year of 2013. At the same time, electricity generated in gas-powered plants decreased by $4.6 \mathrm{TWh}$.

Therefore, the major stake of Germany's electricity production in the first half of 2013 originates from coal-fired power plants (lignite-based power plants 72.9 TWh, hard coal-based power plants 57.4 TWh). Germany's nuclear power stations added 46 TWh and gas-fired power plants 21.9 TWh to the total electricity production. $37 \mathrm{TWh}$ derive from solar- and wind power plants (Mayer et al., 2013).

These findings are a cause of concern as, due to their too high utilization, climatedamaging coal-fired power plants continue to force flexible gas power stations out of the market. But exactly these flexible gaspowered generation units are urgently needed for the success of the Energiewende. They perfectly supplement fluctuating electricity production from renewable sources. It does not take a rocket scientist to realize that in the long-term, this development is leadingdirectly to aninsurmountable system conflict.

The Fraunhofer ISE is therefore pleading for a "coordination of the expansion of renewable energies and the adjustment of conventional power generation units that adopt the present requirements already at an 
early stage" (Mayer et al., 2013, own translation). For the ISE experts this step is "essential" (Ibid.) for the success of the Energiewende.

An incredibly important regulatory instrument for achieving the complete transformation of Germany's energy sector would be a functioning emission trade scheme. Once established, it would increase the price for electricity from climatedamaging coal-fired power plants and consequently stimulate investments in climate-friendly technologies. Unfortunately, in April 2013, the Parliament of the European Union voted against the steady drop in available $\mathrm{CO}_{2}$ certificates and against a rise in costs for pollution rights (Vorholz, 2013). As a result, the German as well as European climate protection lost an important regulatory instrument.

The consequences of thispolicy of sinking $\mathrm{CO}_{2}$ prices are grotesque as the increase in coal-based electricity production absurdly increases the EEG ${ }^{2}$-levy and therefore the costs for the German Energiewende in total! While operators of lignite power stations must feel as winners after having perceived the EU's stand on the pollution rights trade, operators of gas-powered plants as well as the wind and solar industry are losing ground in contrast.

The alternative to an EU-wide emission trading scheme would be the introduction of a carbon dioxide tax. Besides its positive effect on the climate and the environment, this tax would generate the financial basis for a reduction of Germany's electricity tax. This measure alone would noticeably alleviate electricity expenses for private customers. Additionally, the EEG levy would also be noticeably minimized. "Together with the reduction of industry privileges the private electricity customer could be alleviated by 4 $\mathrm{c} / \mathrm{kWh}$ in the future", energy expert and founder of the juwi group Matthias Willenbacher analyzed (Press release of the juwi group, 24.09.2013).

If the German government does not want to jeopardize the Energiewende, then the introduction of an emission trade scheme and a $\mathrm{CO}_{2}$ tax must be reconsidered. New incentives for the restructuring of the energygenerating infrastructure are urgently needed. Unfortunately, the introduction of such policies is currently not having a majority backing, even though the Energiewende can already be achieved by 2020 - provided that there is political commitment (Willenbacher, 2013).

Unfortunately, there is a lack of political will by the new German government to continue the Energiewende at the current speed. It is difficult to understand that the expansion targets for renewable energies are going to be dropped in the foreseeable future instead of being increased. A slowed down expansion of renewable energies will, however, unnecessarily increase the costs for the Energiewende in total (Quaschning, 2013). The longer conventional power plants are in full operation, the longer investment incentives in new, climate-friendly technologies are being prevented. Energy costs will continue to increase as fossil resources are simply finite. Additionally, further costs for the elimination of damages to the environment must be taken into account. The bottom line is: Europe's economic powerhouse is going to pay a very high price for slowing down the Energiewende as even Germany's leadership in green technologies would be threatened severely.

Only the conventional energy industry would benefit fromslowing down the energy

\footnotetext{
2 for further information on the EEG scheme see: (IWR- institute for renewable energy, 2012).
} 
transition. They could continue to operate their power plants with maximum utilization. Private consumers, our climate and our environmentonly come off second-best.

\section{THE ALTERNATIVE TO ELECTRICITY PRODUCTION FROM NUCLEAR AND FOSSIL FUELS: 100 PERCENT RENEWABLE ENERGIES UNTIL 2020}

Germany is able to satisfy its energy demand with 100 percent renewable energies. In his Masterplan (Willenbacher, 2013), juwi-CEO Willenbacher states that wind energy alone can provide 60 percent of Germany's electricity demand. 25 percent can be provided from solar energy. Water power contributes another five percent as this energy source cannot further be utilized in Germany. The remaining ten percent can be satisfied with cogeneration units. These units could burn biogas, producing electricity and useable heat simultaneously.

Willenbacher also explains that for 60 percent wind power, the aesthetics of Germany's countryside does not have to be destroyed, as opponents of the wind industry continuously repeat (Dohmen \& Hornig, 2004). In fact, quite the opposite is true. According to Willenbacher, no more than 25,000 wind turbines are needed for achieving the 60 percent goal. This corresponds roughly to the total amount of currently installed wind turbines in Germany $^{3}$ (Deutsche Wind Guard, 2013). All this is made possible through repowering and technological advancement. What is needed are modern wind turbines of the latest generation with preferably consistent capacity utilization.

The hours at full load must therefore be doubled from now 2,000 up to 4,000 as within these parameters the ratio between utilization and yield is optimal. "Consequently, it is the most economical solution, especially when taking grid connection as well as storage costs into account" (Willenbacher, 2013), Willenbacher further states. According to his master plan, this approach is also easily implementable. It is basically the wind turbine's generator that needs to be optimally utilized. This can be achieved with smaller generators and longer rotor blades of about 120 meters. With this configuration and higher towers it is possible to constantly achieve high numbers of hours at full load, even in so-called low wind areas on shore.

Technical improvements can also lead to better results with photovoltaic plants. Again, all it takes is the increase in hours at full load from today 1,000 up to 2,000 hours. Therefore, the inverter size needs to be designed smaller in relation to the module surface. By adopting these changes, the numbers of hours at full load aregoing to be increased as well as the plant's energy yield, especially in winter times.

With these cost-efficient measures in place, an energy supply based on 100 percent renewables is feasible. According to Willenbacher, hismasterplan is also more cost-effective than the approach currently favored by the German government.

Why is that? Willenbacher confronts the government's offshore ambitions with the decentralized expansion of renewable energies. When the wind turbine's yields are improved and electricity is produced locally where it is actually needed, the expensive offshore plans become superfluous. Wind turbines in the North and Baltic Sea will no longer be needed and thus, the timeconsuming as well as very expensive

$\overline{3}$ End of 2013,23,645 onshore wind turbines were installed in Germany. 
construction of high-voltage grids from North- to South Germany will become almost unnecessary.

With the decentralized expansion of renewable energies less storage capacity is needed aseven the temporarily stored kilowatt hour increases the price for the Energiewende: A previously stored kilowatt hour of electricity is two to three times more expensive than the directly consumed kilowatt hour. The simple reason: Storage capacities are only needed temporarily. This in turn causes higher operational costs. Additionally, storing electricity comes with losses. The investment costs, however, remain constant.

It thus becomes obvious that electricity generated off shore is two to three times more expensive than electricity generated on shore. What is more, there are also the expenses for the grid connection and for the further transport to the industrial zones in South- and Southwest Germany.

For that reason, Willenbacher considers the government's off shore ambitions the real cost drivers of the German Energiewende. "Basically, the four major players on the German energy market are the only ones benefitting from off shore as this approachis simply too expensive for local utilities or energy cooperatives. With off shore wind parks Germany's energy oligolopolycan continue dominating the energy market while keeping their coal fired power plants in operation simultaneously to their new playing grounds in the North- and Baltic Sea", Willenbacher states (Willenbacher, 2013).

Instead of investing in off shore wind projects and new grids, the German government should rather invest in cogeneration units that produce electricity anduseful heat simultaneously without great losses. This is also part of Willenbacher's masterplan: With the calculated 20 to 30 billion Euros that are needed in order to finance the grid expansion, up to 50,000 Megawatts of cogeneration units could be installed instead. These small scale power plants could be used for generating biogas based electricity for the industry and other bulk consumers at competitive prices. This, in turn, would improve the competitiveness of these companies.

Prospectively, mini-cogeneration units could be installed in every building. In addition to this, back up batteries for solar energy or batteries of electric cars can be utilized whenever they are not in use - which is usually 90 percent of the day.

Willenbacher is, however, not planning to operate cogeneration units around the clock. These units should instead be used whenever there is not enough climate-friendly electricity provided from the wind and the sun. Despite their good energy balance, resources for the production of biogas still cost money while wind and sun do not issue any invoices. Their energy is for free.

Besides the production of electricity, consumption needs to be controlled in an intelligent way, too. It is already possible to adjust the electricity demand to times of high electricity production. Thus, washing machines can be used in times of high solar energy production - preferably at midday.

\section{CONCLUSION AND OUTLOOK}

So far, the German Energiewende has been proven a success story. The instrument that significantly boosted the expansion of renewables is the German Renewable Energy Act (EEG) implemented in the year 2000. At least 65 countries adapted a similar 
concept in order to accelerate their renewable energy sector. In its 2011 status report, the German Government classified the impact of the EEG as "exceptionally successful" (Bundesregierung, 2011, own translation). No wonder: The system of fixed feed-in tariffs has been proven superior to other concepts, such as the quota system. It ensures the lowest possible costs and a steady expansion of renewable energies. Additionally, the system of fixed feed-in tariffs is also the most cost-efficient.

While the price for electricity generated in conventional power plants is significantly determined by fuel costs (inclusive $\mathrm{CO}_{2}$ certificates), the price for electricity from wind and solar power plants is only determined by fixed costs. Fixed feed-in tariffs primarily serve to refinance the investments into the power plants. Furthermore, fixed tariffs are an excellent basis for investment decisions as they guarantee exactly the tariff that is needed for operating a renewable energy plant.

Of course, the EEG needs to be adjusted from time to time in order to deal with the changing situations on the energy production market. However, an overly narrowed focus on electricity costs alone will definitely not accelerate the Energiewende. The most costefficient way of reliably producing clean and safe electricity is still the decentralized expansion of renewable energies.

What makes the Energiewende expensive are the billions of Euros needed for the grid expansion from North- to South Germany in order to connect off shore wind parks.

Two main factors can be identified that are essential for the furtherdevelopment of the Energiewende: First, the quick and complete restructuring of Germany's energy production market and second, certainty for investors. Particularly the latter is of utmost importance. Cheap propaganda against renewable energies is dangerous and counter-productive as it deters potential investors. Unfortunately, this is what is happening at the moment. The four major players on the German energy market together with lobbyists in Berlin are reacting against the further expansion of renewables as this development further threatens their business model. It is a matter of fact that they simply have not invested in renewable energies for the past 20 years. Today, about 50 percent of all renewable energy plants are owned by individuals, local utilities or energy associations. The four major player on the German energy market only own about five percent.

The big player's attitude against renewable energies are perfectly represented by former RWE CEO Jürgen Grossmann who once stated that solar energy in Germany would be as useful as growing pineapples in Alaska. Grossmann and RWE, however, were overtaken by reality just two years later. Due to investments in the wrong technologies the company's new CEO just had to present the shareholders a 2.8 billion deficit.

Today, more than 25 percent of Germany's electricity production comes from renewable sources. With a bit more enthusiasm and political commitment to Willenbacher's decentralized expansion scenario, the Energiewendecan be achieved much more cost-effectively and as early as 2020. The technologies are already in place. For a greener future, they just need to be eployed. 


\title{
ЗАШТО НАМ ЈЕ ПОТРЕБНА 100 ПРОЦЕНТНО ОБНОВЉИВА ЕНЕРГИЈА: РАЗЛОГ ЗА РАЗВОЈ КОНЦЕПТА "ЕNЕRGIEWENDE"
}

\author{
Christian Hinsch, Felix Wächter
}

Извод

Они који су упознати са петим међувладиним панелом публикованим у извештају о промени климе, који је представљен крајем 2013. не могу озбиљно сумњати у то да су климатске промене постале реалност. Иако је овај аспект био предмет неколико високопрофилних интернационалних конференција, мало је постигнуто до сада. Термоелектране које раде на фосилна горива и даље емитују велике количине гасова и тиме додатно убрзавају промену климе. Ипак, постоји алтернатива тренутном начину производње енергије - који има нагативан ефекат на климу: прелазак на 100 постотно обновљиве изворе енергије. Овај рад истражује начин на који индустријализована земља као што је Немачка може постати 100 посто снабдевена обновљивом енергијом до 2020. године.

Кључне речи: "Energiewende", обновљива енергија, Немачка, прелазак, фосилна горива, "Matthias Willenbacher", "Juwi"

\section{References}

BDEW, B.-u. (27. 5 2013). BDEWStrompreisanalyse 2013. Abgerufen am 18. $02 \quad 2014$ von www.bdew.de: http://www.bdew.de/internet.nsf/id/123176A BDD9ECE5DC1257AA20040E368/\$file/13 $\% 2005 \% 2027 \% 20$ BDEW_Strompreisanalys e_Mai\%202013.pdf

Bundesregierung.

Erfahrungsbericht 2011 zum ErneuerbareEnergien-Gesetz. Berlin.

Deutsche Wind Guard. (2013). Status des Windenergieausbaus an Land in Deutschland. Varel.

Dohmen, \& Hornig. (2004). Die große Luftnummer. DER SPIEGEL, 80.

Emnid, T. (2013). Hintergrundpapier zur Pressekonferenz der Initiative Erneuerbare Energiewende Jetzt!Berlin: Energiewende Jetzt!

IPCC. (2013). Acceptance of the Actions taken at twelfth Session of working group I. Approved summery for policy makers.
Intergovernmental panel on climate change. Thirty-sixth session of the IPCC, (S. 37). Stockholm.

IWR. (17. 02 2013). www.iwr.de. Abgerufen am 17. 022013 von Deutsche Atomkraftwerke verbrauchen selbst mehr Strom als das Bundesland Bremen: http://www.iwr.de/

IWR- institute for renewable energy. (2012). IWR. Abgerufen am 26. 022014 von Renewable energy is subsidised - The state does not pay a cent: http://www.iwrinstitut.de/en/press/backgroundinformations/renewable-energy-is subsidised-the-state-does-not-pay-a-cent

Küchler, Meyer, \& Blanck. (2012). Was Strom wirklich kostet. Vergleich der staatlichen Förderungen und gesamtgesellschaftlichen Kosten von konventioneller und erneuerbaren energien.

Mayer, Kreifels, \& Burger. (2013). Kohleverstromung $\mathrm{zu}$ Zeiten niedriger Börsenstrompreise. ISE.

Mineralölwirtschaftsverband e.V.; 
(2013). Roölpreisentwicklung 1960-2012.

Quaschning, V. (2013). Das Imperium schlägt zurück. Wirtschaftswoche green.

Scheer, H., Alt, F., \& Claus, J. (1998). Windiger Protest. Konflikte um das Zukunftspotenzial der Windkraft.

Schneider, M. (05. 10 2013). www.klimaretter.info. Abgerufen am 27. 01 2014

von http://www.klimaretter.infi/energie/hintergru nd/14709-krise-der-atomkraft-in-den-usa

Schneider, M., \& Frogatt, A. (2013). World Nuclear Industry Status Report 2013.Paris, London.

Schumann. (2013). Die Industrie verbreitet Lügen bei Strompreisen. DIE ZEIT.

Vorholz. (18. 04 2013). Verrat am Klimaschutz. Abgerufen am 17. 102013 von DIE ZEIT online: http://www.zeit.de/2013/17/eu-parlamentreform-emissionshandel

Willenbacher, M. (2013). Mein unmoralisches Angebot an die Kanzlerin. Denn die Energiewende darf nicht scheitern. Herder Verlag.

Wirth. (2013). Aktuelle Fakten zur Photovoltaik in Deutschland. Fraunhofer ISE. 